\title{
Power Management of Standalone Hybrid PV-Micro Hydro Battery Energy Storage System using Fuzzy Logic Controller
}

\author{
Melese Loha Anjulo \\ Beshiro Gute Village, Sidama Zone, Ethiopia, \\ B.Sc., Electrical Engineering and M.Sc., Power System and Energy Engineering \\ Department of Electrical and computer Engineering, Hawassa University \\ Senior Electrical Engineer, SNNPRS Industrial Parks Development Corporation \\ Hawassa, Ethiopia
}

\begin{abstract}
Integration of renewable energy sources at distributed level can be good solution for providing reliable electricity to rural areas. Further, the management of these renewable energy systems is very vital. The study area has on average $5.83 \mathrm{kwh} / \mathrm{m} 2 / \mathrm{d}$ solar radiation and average flow rate of $0.3 \mathrm{~m} 3 / \mathrm{s}$. There are generally two types of loads (household and commercial) with total electric demand of $35.653 \mathrm{KW}$. The proposed management system is implemented with fuzzy logic controller and at the same time to maintain the battery state of charge (SOC) with in allowable limits. The load power response using fuzzy logic controller was compared with conventional proportional integral (PI) controller. The results obtained show that in spite of sudden load changes and variations in the power generation, the power balance between the supply and demand effectively maintained by the developed fuzzy logic based controller (FLC). Various components of hybrid system are modeled and simulated in MATLAB/ Simulink and the parameters are controlled and calibrated by the fuzzy logic toolbox.
\end{abstract}

Keywords: Power management, hybrid energy system, PI controller and fuzzy logic controller.

\section{NTRODUCTION}

The development of renewable energy based on locally available resource should play a key role. Ethiopia has a huge renewable energy (hydro power, solar, biomass, wind energy and etc.) potential that are attempted for rural electrification. The more noticeable benefits of usable electric power include: improved healthcare, improved communication system, a higher standard of living and economic stability. Many of the rural areas of Ethiopia are attempting to benefit from these uses of electricity in the same proportion as the more populated urban areas of the country $[1,2,3]$. The Beshiro Gute village is one of those rural areas which have access to electricity by means of micro hydro power plant. The community requires electricity for house equipment like TV, Radio player, lighting, barber shop, milling machine and others. Hybrid power generation systems that combine different renewable energy sources and energy storage systems offer an environmentally friendly alternative for standalone operations. However, there are several challenges for the hybrid power system. Appropriate control and coordination strategies among various elements of the hybrid system are required so it can deliver required power.
Due to the nature of intermittence of renewable energy, the use of the secondary energy storage such as batteries become inevitable this will compensate the fluctuation of power generation.

\section{II.MODELING OF HYBRID SYSTEM COMPONENTS}

The hybrid system consists of three power generation systems, photovoltaic arrays, a micro hydro power and battery bank. The PV and micro hydro are used as the main power generation for the system and the battery bank is assigned as a backup power generator for the continuous power supply. Figure 1 below shows schematic diagram of interconnection of components of a developed hybrid PV micro hydro with battery energy storage system.

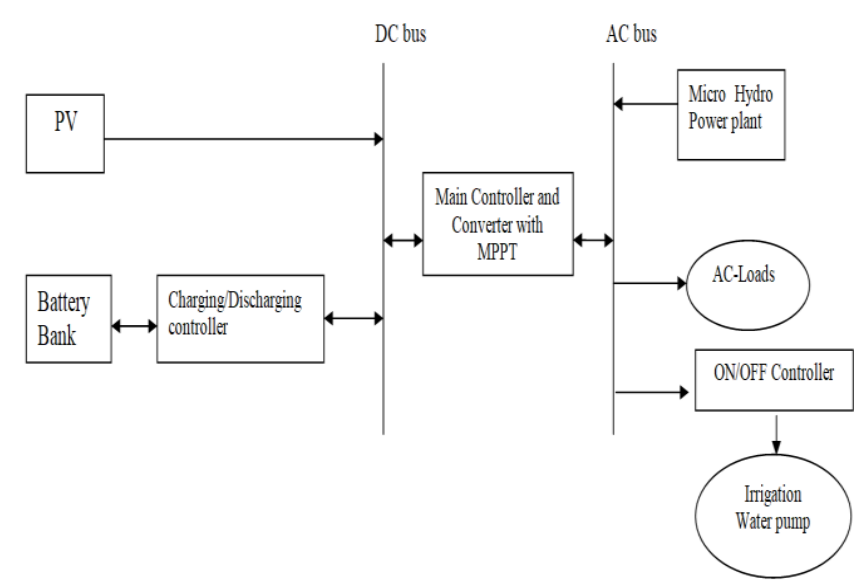

Fig 1: Block diagram of developed hybrid PV - micro hydro with battery energy storage system

A. Modeling of Solar-Photovoltaic Generator Using the solar radiation available, the hourly energy output of the PV generator;

$\mathrm{E}_{\mathrm{PVG}}=\mathrm{G}(\mathrm{t}) \times \mathrm{A} \times \mathrm{P} \times \eta_{\mathrm{PVG}}$

Where;

$\mathrm{E}_{\mathrm{PVG}}$ is the hourly energy output of the PV generator

$\mathrm{G}(\mathrm{t})$ the hourly irradiance in $\mathrm{kWh} / \mathrm{m}^{2}$

$A$ is the surface area in $\mathrm{m}^{2}$

$\mathrm{P}$ is the PV penetration level factor

$\eta_{\text {PVG }}$ is the efficiency of PV generator 


\section{B. $\quad$ Modeling of Micro Hydro}

Power obtained from hydropower generator can be given as

$\mathrm{P}=\mathrm{Q} \times \mathrm{H} \times \mathrm{e} \times \mathrm{g}(\mathrm{kW})$

Where

P: Generator Output Power $(\mathrm{kW})$

$\mathrm{H}$ : The water head in meters $(\mathrm{m})$

Q: The water flow $\left(\mathrm{m}^{3} / \mathrm{s}\right)$

e: The total efficiency, overall efficiency of hydropower generator $(\%)$

g: 9.81 is a constant, acceleration due to gravity in $\mathrm{m} / \mathrm{s}^{2}$

\section{Modeling of Converter}

In the developed scheme, a converter contains both rectifier and inverter. PV energy generator and battery subsystems are connected with DC bus while micro hydro generating unit subsystem is connected with $\mathrm{AC}$ bus. The electric loads connected in this scheme are AC loads.

The rectifier model is given below:

EREC-OUT $_{(t)}=$ E REC-IN $_{\text {R }}(t) \times \eta_{\text {REC }}$

$\mathrm{E}_{\text {REC-IN }}(\mathrm{t})=\mathrm{E}_{\text {SUR-AC }}(\mathrm{t})$

At any time $t$,

$E_{S U R-A C}(t)=E_{M H G}(t)-E_{L O A D}(t)$.

The inverter model for photovoltaic generator and battery bank are given below:

$\mathrm{E}_{\text {PVG-IN }}(\mathrm{t})=\mathrm{E}_{\mathrm{PVG}}(\mathrm{t}) \times \eta_{\mathrm{INV}}$,

$\mathrm{E}_{\text {BAT-INV }}(\mathrm{t})=\left[\left(\mathrm{E}_{\text {BAT }}(\mathrm{t}-1)-\mathrm{E}_{\text {LOAD }}(\mathrm{t})\right) /\left(\eta_{\text {INV }} \times \eta_{\text {DCHG }}\right)\right]$

Where;

$\mathrm{E}_{\text {REC-OUT }}(\mathrm{t})$ is the hourly energy output from rectifier, $\mathrm{kWh}$

$E_{\text {REC-IN }}(t)$ is the hourly energy input to rectifier, $\mathrm{kWh}$

ESUR-AC $_{\text {( }}($ ) is the amount of surplus energy from AC sources, $\mathrm{kWh}$

$\mathrm{E}_{\mathrm{MHG}}$ is the hourly energy generated by micro hydro generator, $\mathrm{kWh}$

$\mathrm{E}_{\mathrm{LOAD}}(\mathrm{t})$ is energy supplied to the load, (kWh)

$\mathrm{E}_{\text {PVG-IN }}(\mathrm{t})$ is the hourly energy output from inverter, $\mathrm{kWh}$

$E_{P V G}(t)$ is the hourly energy output of the PV generator

$\eta_{\text {REC }}$ is the efficiency of rectifier

$\eta_{\text {INV }}$ is the efficiency of inverter

$\eta_{\text {DCHG }}$ is the battery discharging efficiency

$\mathrm{E}_{\text {BAT-INV }}(\mathrm{t}$ ) is the hourly energy output from inverter (in case of battery), $\mathrm{kWh}$

$\mathrm{E}_{\mathrm{BAT}}(\mathrm{t}-1)$ is the energy stored in battery at hour $\mathrm{t}-1, \mathrm{kWh}$

\section{Modeling of Charge Controller}

To prevent overcharging of a battery, a charge controller is used to sense when the batteries are fully charged and to stop or reduce the amount of energy flowing from the energy source to the batteries. The model of the charge controller is presented below:
$\mathrm{E}_{\text {CC-OUT }}(\mathrm{t})=\mathrm{E}_{\mathrm{CC}-\mathrm{IN}}(\mathrm{t}) \times \eta_{\mathrm{CC}}$

$E_{\text {CC-IN }}(t)=E_{\text {REC-OUT }}(t)+E_{\text {SUR-DC }}(t)$

Where;

$\mathrm{E}_{\text {CC-OuT }}(\mathrm{t})$ is the hourly energy output from charge controller, $\mathrm{kWh}$

$\mathrm{E}_{\mathrm{CC}-\mathrm{NN}}(\mathrm{t})$ is the hourly energy input to charge controller, $\mathrm{kWh}$

$E_{\text {SUR-DC }}$ is the amount of surplus energy from DC source (PV panels); kWh

$\eta_{\text {cc }}$ is the efficiency of charge controller

\section{E. Modeling of Battery Bank}

During the charging process, when the total output of all generators exceeds the load demand, the available battery bank capacity at time,

$\mathrm{E}_{\mathrm{BAT}}(\mathrm{t})=\mathrm{E}_{\mathrm{BAT}}(\mathrm{t}-1)-\mathrm{E}_{\mathrm{CC}-\mathrm{OUT}}(\mathrm{t}) \mathrm{X} \eta_{\text {CHG }}$

On the other hand, when the load demand is greater than the available energy generated, the battery bank is in discharging state. Therefore, the available battery bank capacity at time $t$,

$\mathrm{E}_{\mathrm{BAT}}(\mathrm{t})=\mathrm{E}_{\mathrm{BAT}}(\mathrm{t}-1)-\mathrm{E}_{\text {Needed }}(\mathrm{t})$

Where;

$\mathrm{E}_{\text {BAT }}(\mathrm{t})$ is the energy stored in battery at hour $\mathrm{t}, \mathrm{kWh}$

$\mathrm{E}_{\mathrm{BAT}}(\mathrm{t}-1)$ is the energy stored in battery at hour $\mathrm{t}-1, \mathrm{kWh}$

$E_{\text {CC-OuT }}(t)$ is the hourly energy output from charge controller, $\mathrm{kWh}$

$\mathrm{E}_{\text {Needed }}(\mathrm{t})$ is the hourly load demand or energy needed at a particular period of time

$\eta_{\text {CHG }}$ is the battery charging efficiency.

\section{RENEWABLE ENERGY RESOURCE ASSESSMENT AND LOAD PROFILE}

\section{A. Solar Resource Assessment}

Daily averages of the world solar radiation based on horizontal surfaces can be obtained from the NASA Surface Meteorology and NASA solar energy website. Annual average global solar radiation per day of the study area is $5.83 \mathrm{kWh} / \mathrm{m}^{2} /$ day. The low global radiation relatively seen between July to October because this period is cloudy and rainy. Besides that, the clearness index monthly average is about 0.583 .

Table 1: Average monthly radiation of the village (source:

NASSA) [4]

\begin{tabular}{|c|l|l|}
\hline Month & Clearance index & Daily radiation $\mathbf{k W h} / \mathbf{m}^{2} /$ day \\
\hline January & 0.621 & 6.25 \\
\hline February & 0.635 & 6.60 \\
\hline March & 0.613 & 6.44 \\
\hline April & 0.583 & 5.95 \\
\hline May & 0.602 & 5.81 \\
\hline June & 0.574 & 5.34 \\
\hline July & 0.515 & 4.86 \\
\hline August & 0.522 & 5.18 \\
\hline September & 0.550 & 5.68 \\
\hline October & 0.549 & 5.69 \\
\hline November & 0.605 & 6.11 \\
\hline December & 0.623 & 6.17 \\
\hline Average & 0.583 & 5.83 \\
\hline
\end{tabular}




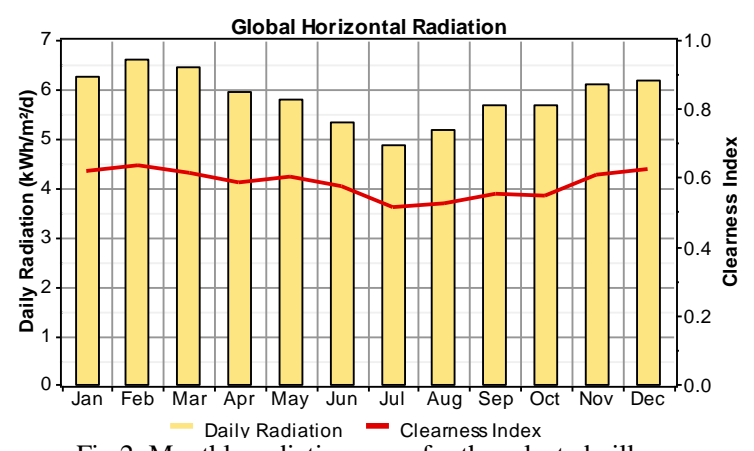

Fig 2: Monthly radiation sums for the selected village

\section{B. Hydrological Data Assessment}

The maximum discharge was happened in the rainy season (June to September) while the minimum flow happened in dry season of the year which was from October to February $[5,6]$.

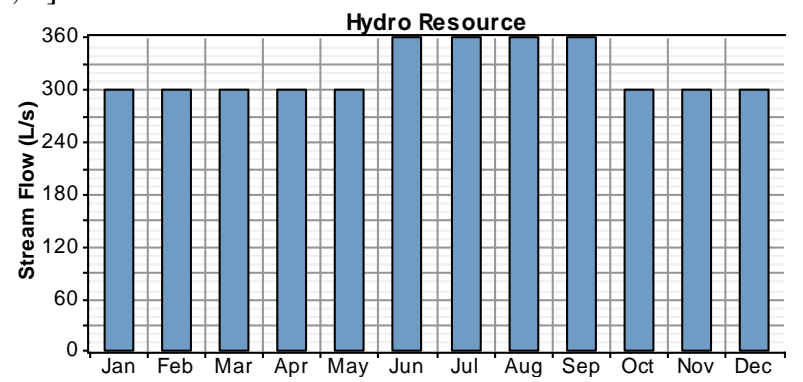

Fig 3: Monthly discharge of Ererte River at the gauging site

According to the local people information the river is a perennial river and considering the dry season water reduction the design flow can be fixed at $300 \mathrm{l} / \mathrm{s}$ or $0.3 \mathrm{~m}^{3} / \mathrm{s}$.

C. Village Load Profile

The load profile of the village has been derived from data gathered via GIZ Ethiopia and SNNPRS Mining and Energy agency [5, 6]. Survey form for households can be summarized as below.

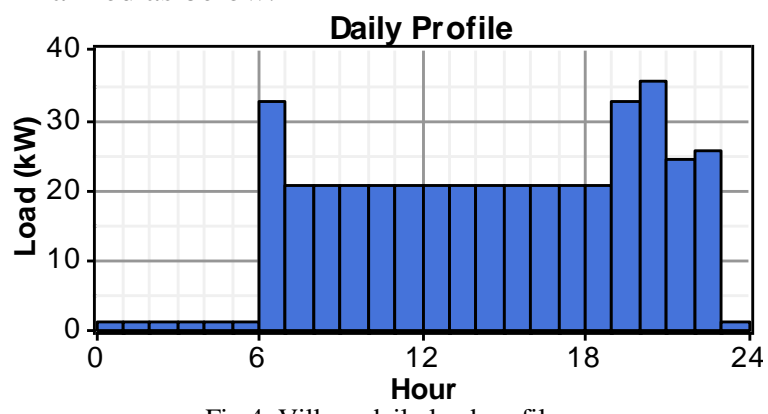

Fig 4: Village daily load profile

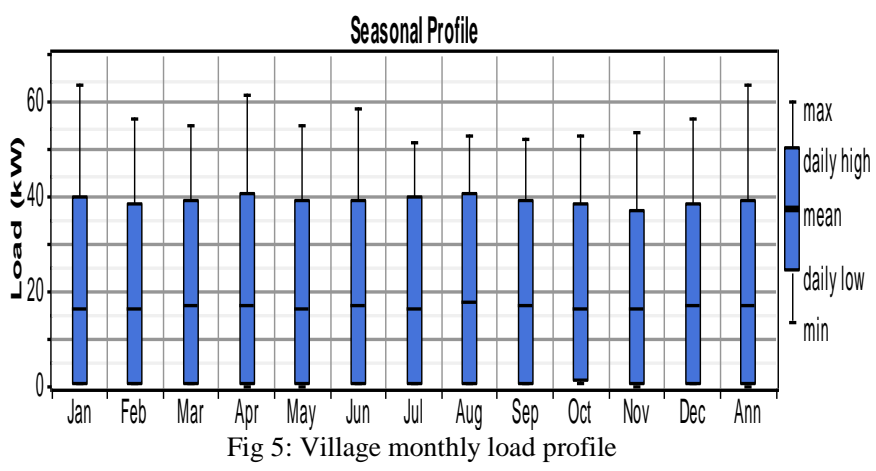

\section{FUZZY LOGIC CONTROLLER BASED} POWER MANAGEMENT

\section{A. Basic Concept of Fuzzy Logic Control}

Fuzzy logic idea is similar to the human being's feeling and inference process. Unlike classical control strategy, which is a point-to-point control, fuzzy logic control is a range-to-point or range-to-range control. The output of a fuzzy controller is derived from fuzzificaton of both inputs and outputs using the associated membership functions. A crisp input will be converted to the different members of the associated membership functions based on its value. From this point of view, the output of a fuzzy logic controller is based on its memberships of the different membership functions, which can be considered as a range of inputs [7].

To implement fuzzy logic technique to a real application requires the following three steps:

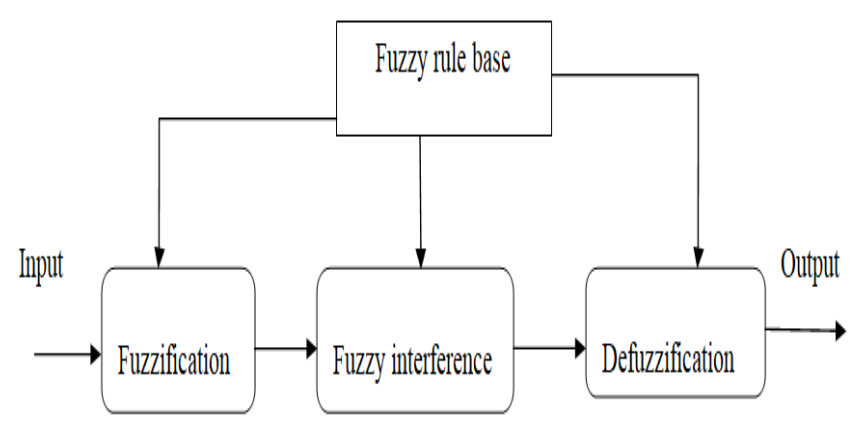

Fig 6: Structure of a fuzzy control system [7]

The power management strategy flowchart of controlling the PV micro hydro battery hybrid system using FLC is shown in Figure 7.

Depending on the load demand and available power, the controller selects individual source or combination of sources that will meet the load demand. It will also control the battery state of charge (SOC) by activating the charger control switch when there is excess power from primary sources and activates the discharging switch in case of primary sources do not meet the load demand. Provided that the loads can't use up the whole output power, and the battery is fully charged, the surplus power is then sent to the irrigation water pump.

The FLC relates the outputs to the inputs using a list of IFTHEN statements called rules. The if-part of the rules describes the fuzzy set (Regions) of the input variables. In this work, the fuzzy input variables are PG, PL, and SOC and output variables are irrigation WP, BS. Where PG, PL, SOC and WP are the generated power, load power, battery state of charge and irrigation water pump states. All four inputs have three (3) trapezoidal membership function such as Low, Medium and High (L, M, H) and all output have two membership function (ON and OFF). The degrees of membership are evaluated to obtain the output controller, and the then-parts of all rules are averaged and weighted by the degrees of membership. 


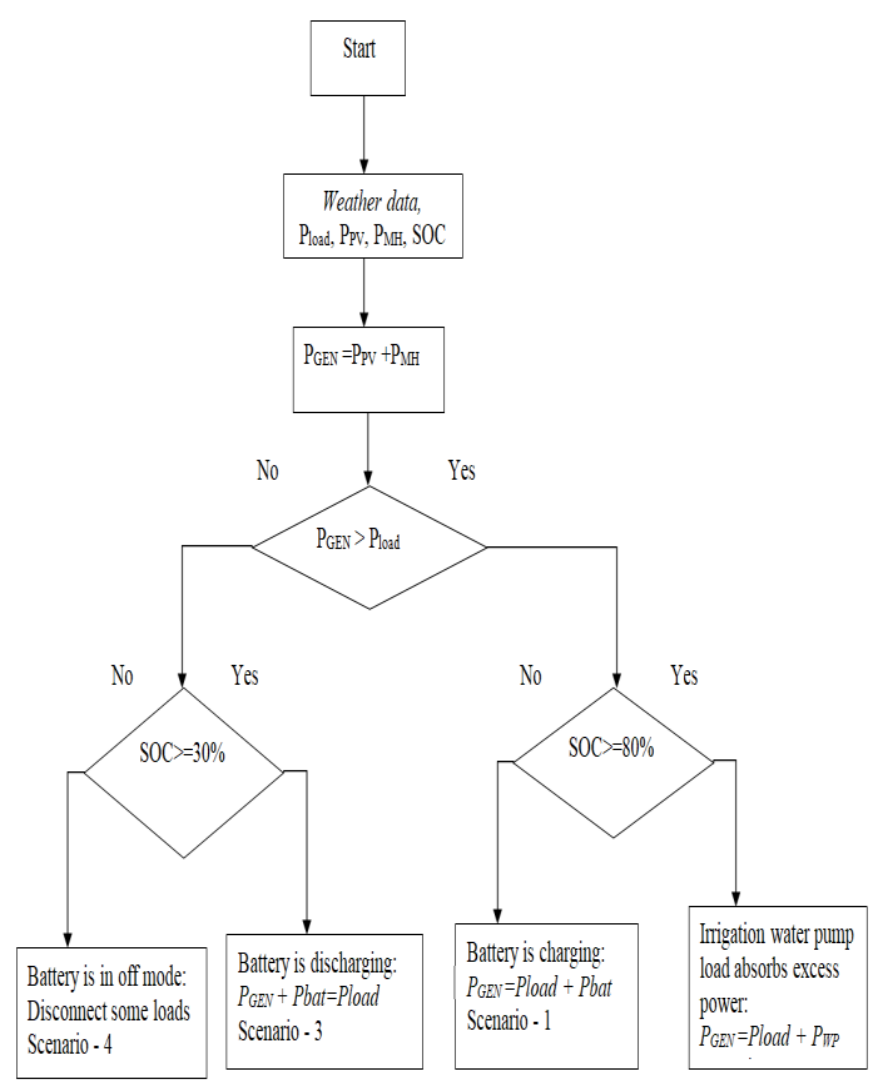

Fig 7: Control strategy for PV-micro hydro with battery energy storage system

As shown in the figure 7 above, the system operates in 4 Scenarios. For all the scenarios total power generation $\mathrm{P}_{\text {gen }}$ (PV plus micro hydro power) is measured first then it compares with load demand $\mathrm{P}_{\text {load, }}$ and SOC are measured. Different modes of operation are given below,

\section{i. Scenario -1}

In this mode $\mathrm{P}$ gen is greater than $\mathrm{P}_{\text {load }}$ and SOC is less than $80 \%$, battery will be charged. In this mode the buck mode of the buck-boost converter will be in operation according to the controller battery reference power $\mathrm{P}_{\text {batref. So the }}$ power balance equation is

$$
\mathrm{P}_{\text {gen }}=\mathrm{P}_{\text {load }}+\mathrm{P}_{\text {bat }}
$$

\section{ii. Scenario -2}

$\mathrm{P}_{\text {gen }}$ is more than $\mathrm{P}_{\text {load }}$ and SOC is more than $80 \%$, battery will not be charged as it touches its maximum limit. In this mode the controller output will be zero. So the battery will not be charged or discharged that is it will be in cut off position. So the irrigation water pump starts its operation. The power balance equation is

$$
\mathrm{P}_{\text {gen }}=\mathrm{P}_{\text {load }}+\mathrm{P}_{\text {pump }}
$$

Irrigation water pump absorbs the excess power.

\section{iii. Scenario -3}

$\mathrm{P}_{\text {gen }}$ is lower than $\mathrm{P}_{\text {load }}$ and SOC is more than $30 \%$, battery should be discharged to meet the load. In this mode the boost mode of the buck-boost converter will be in operation according to the controller battery reference power $\mathrm{P}_{\text {batref. }}$ The power balance equation is

$$
\mathrm{P}_{\text {gen }}+\mathrm{P}_{\text {bat }}=\mathrm{P}_{\text {load }}
$$

\section{iv. Scenario -4}

$\mathrm{P}_{\text {gen }}$ is lower than Pload and SOC is less than $30 \%$, so battery will not discharge and system needs to shade some amount of load to balance the demand and supply.

A Fuzzy Logic Designer. MElésE LOHA

File Edit View

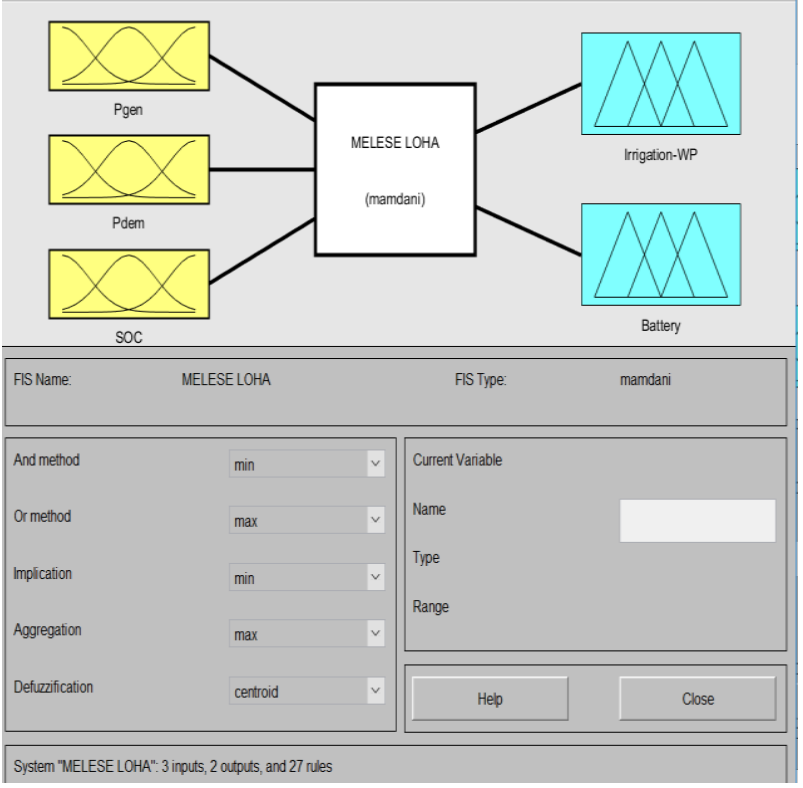

Fig 8: Fuzzy logic designer of the control system

In the above figure 8 there are three inputs variables; power generated, power demand and state of charge of battery and two output variables; battery control and irrigation water pump control. The ranges of input and output variables membership functions are described in the tables 2, 3, and 4 below.

Table 2: The ranges of input variables membership

function
\begin{tabular}{|l|l|l|l|}
\hline \multicolumn{1}{|c|}{ Input variables } & Low & Medium & High \\
\hline Power generated $\left(\mathrm{P}_{\mathrm{GEN}}\right)$ in KW & $0-15$ & $10-30$ & $30-42$ \\
\hline Power demand $\left(\mathrm{P}_{\mathrm{LOAD}}\right)$ in KW & $0-10$ & $10-25$ & $25-35$ \\
\hline Battery SOC \% & $0-30$ & $30-80$ & $80-100$ \\
\hline
\end{tabular}

Table 3: The ranges of output variables membership functions

\begin{tabular}{|l|l|l|l|}
\hline $\begin{array}{l}\text { Output } \\
\text { variables }\end{array}$ & Charging & $\begin{array}{c}\text { Charging/Disch } \\
\text { arging }\end{array}$ & Discharging \\
\hline $\begin{array}{l}\text { Battery } \\
\text { controller }\end{array}$ & $0-0.3$ & $0.3-0.8$ & $0.8-1$ \\
\hline
\end{tabular}

Table 4: The ranges of output variables membership functions

\begin{tabular}{|l|c|c|}
\hline Output variables & OFF & ON \\
\hline Irrigation WP controller & $0-0.5$ & $0.5-1$ \\
\hline
\end{tabular}




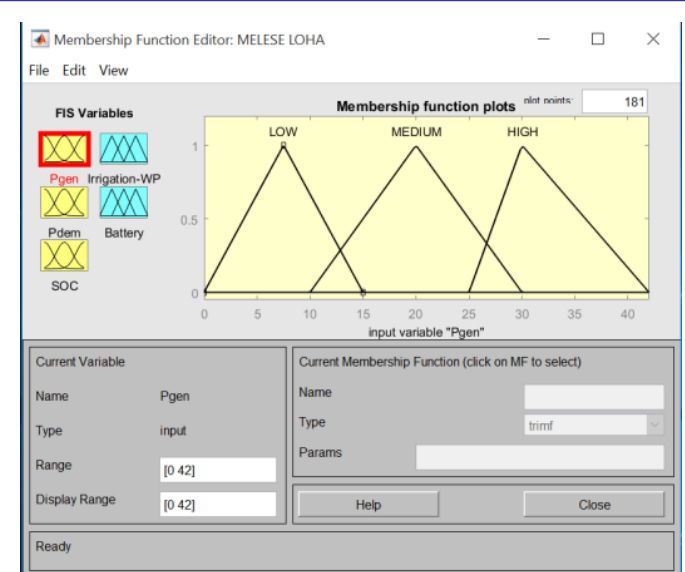

Fig 9: Membership function of power generated

As shown in the figure 9 the ranges of generated power input variables membership functions are described as 0-15 KW (LOW), 10-30KW (MEDIUM) and 25-42KW (HIGH).

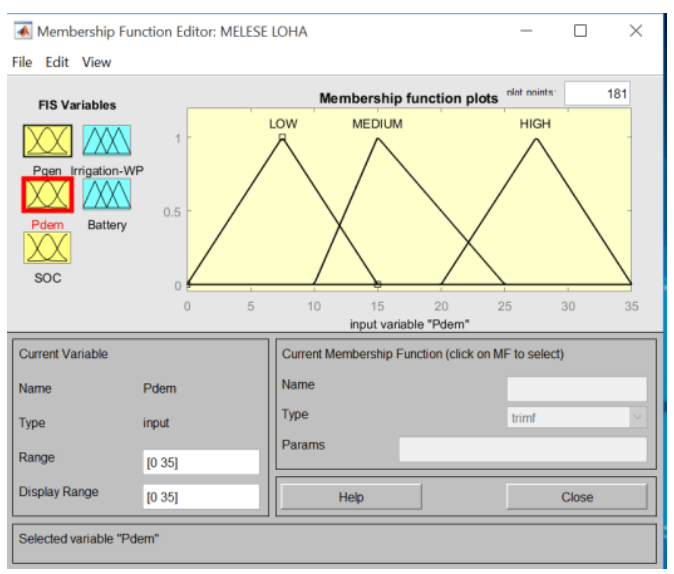

Fig 10: Membership function of power demand

As shown in the figure 10 the ranges of demand power input variables membership functions are described as 0-15 KW (LOW), 10-25KW (MEDIUM) and 20-35KW (HIGH).

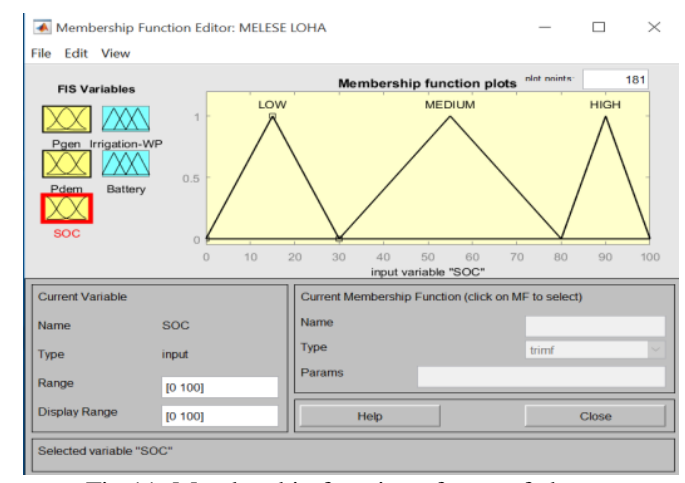

Fig 11: Membership function of state of charge

As shown in the figure 11 the ranges of state of charge of battery input variables membership functions are described as $0-30 \%$ (LOW), $30-80 \%$ (MEDIUM) and $80-100 \%$ (HIGH).

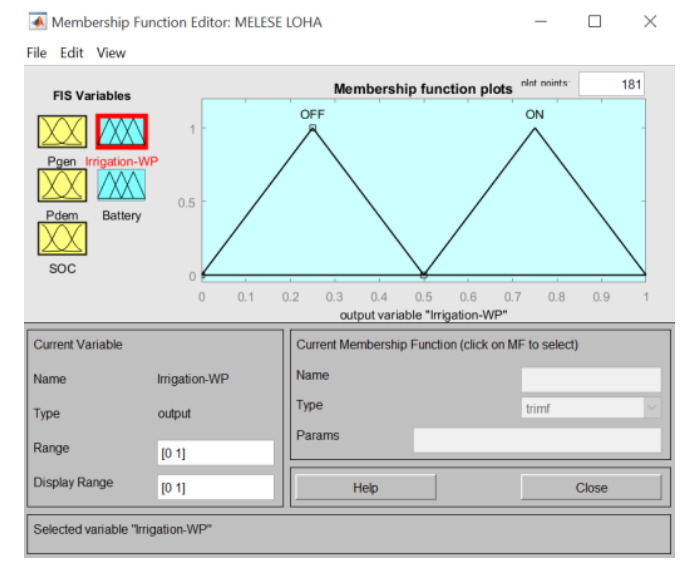

Fig 12: Membership function of irrigation water pump control

As shown in the figure 12 the ranges of irrigation water pump control output variables membership functions are described as $0-0.5(\mathrm{OFF})$ and $0.5-1(\mathrm{ON})$.

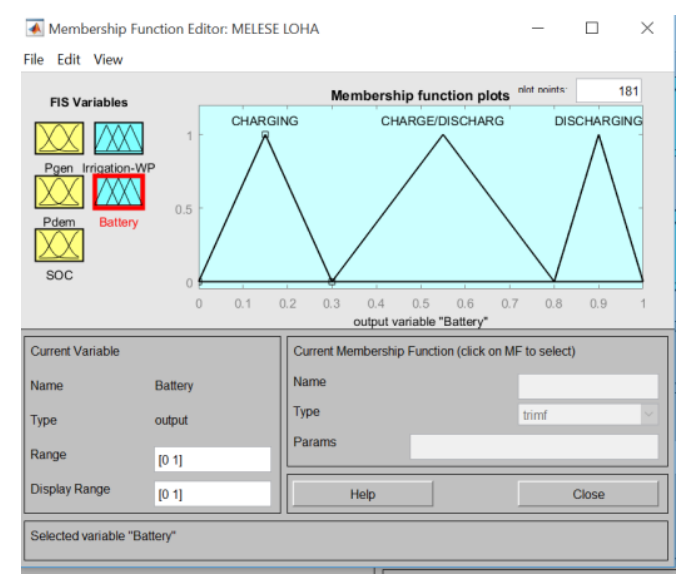

Fig 13: Membership function of battery control

As shown in the figure 13 the ranges of battery control output variables membership functions are described as 0 0.3(CHARGING), 0.3-0.8(CHARGING OR DISCHARGING) and 0.8-1(DISCHARGING).

Table 5: Fuzzy logic rules

\begin{tabular}{|c|c|}
\hline 1 & $\begin{array}{l}\text { IF } P_{\text {GEN }} \text { is } \mathrm{L} \text { and } \mathrm{P}_{\mathrm{L}} \text { is } \mathrm{L} \text { and } \mathrm{SOC} \text { is } \mathrm{L} \text {, THEN WP is OFF and BS is } \\
\mathrm{CO}\end{array}$ \\
\hline 2 & $\begin{array}{l}\text { IF } P_{\text {GEN }} \text { is } \mathrm{L} \text { and } \mathrm{P}_{\mathrm{L}} \text { is } \mathrm{M} \text { and } \mathrm{SOC} \text { is } \mathrm{L}, \text { THEN WP is OFF and } \mathrm{BS} \text { is } \\
\mathrm{CO}\end{array}$ \\
\hline 3 & $\begin{array}{l}\text { IF } P_{G E N} \text { is } \mathrm{L} \text { and } \mathrm{P}_{\mathrm{L}} \text { is } \mathrm{H} \text { and SOC is } \mathrm{L} \text {, THEN WP is OFF and BS is } \\
\mathrm{CO}\end{array}$ \\
\hline 4 & $\begin{array}{l}\text { IF } P_{\text {GEN }} \text { is } L \text { and } P_{L} \text { is } L \text { and SOC is M, THEN WP is OFF and BS is } \\
\text { CD }\end{array}$ \\
\hline 5 & $\begin{array}{l}\text { IF } \mathrm{P}_{\mathrm{GEN}} \text { is } \mathrm{L} \text { and } \mathrm{P}_{\mathrm{L}} \text { is } \mathrm{M} \text { and } \mathrm{SOC} \text { is } \mathrm{M}, \mathrm{THEN} \mathrm{WP} \text { is } \mathrm{OFF} \text { and } \mathrm{BS} \\
\text { is } \mathrm{CD}\end{array}$ \\
\hline 6 & $\begin{array}{l}\text { IF } P_{\text {GEN }} \text { is } \mathrm{L} \text { and } \mathrm{P}_{\mathrm{L}} \text { is } \mathrm{H} \text { and } \mathrm{SOC} \text { is } \mathrm{M} \text {, THEN } \mathrm{WP} \text { is OFF and } \mathrm{BS} \text { is } \\
\mathrm{CD}\end{array}$ \\
\hline 7 & $\begin{array}{l}\text { IF } P_{\text {GEN }} \text { is } \mathrm{L} \text { and } \mathrm{P}_{\mathrm{L}} \text { is } \mathrm{L} \text { and } \mathrm{SOC} \text { is } \mathrm{H} \text {, THEN WP is OFF and BS is } \\
\text { DO }\end{array}$ \\
\hline 8 & $\begin{array}{l}\text { IF } P_{G E N} \text { is } L \text { and } P_{L} \text { is } M \text { and SOC is } \mathrm{H} \text {, THEN WP is OFF and BS is } \\
\text { DO }\end{array}$ \\
\hline 9 & $\begin{array}{l}\text { IF } \mathrm{P}_{\mathrm{GEN}} \text { is } \mathrm{L} \text { and } \mathrm{P}_{\mathrm{L}} \text { is } \mathrm{H} \text { and } \mathrm{SOC} \text { is } \mathrm{H} \text {, THEN WP is OFF and } \mathrm{BS} \text { is } \\
\text { DO }\end{array}$ \\
\hline
\end{tabular}




\begin{tabular}{|c|c|}
\hline 10 & $\begin{array}{l}\text { IF } P_{\text {GEN }} \text { is } M \text { and } P_{\mathrm{L}} \text { is } L \text { and } S O C \text { is } L \text {, THEN WP is OFF and BS is } \\
\text { CO }\end{array}$ \\
\hline 11 & $\begin{array}{l}\text { IF } \mathrm{P}_{\mathrm{GEN}} \text { is } \mathrm{M} \text { and } \mathrm{P}_{\mathrm{L}} \text { is } \mathrm{M} \text { and } \mathrm{SOC} \text { is } \mathrm{L} \text {, THEN } \mathrm{WP} \text { is OFF and } \mathrm{BS} \\
\text { is CO }\end{array}$ \\
\hline 12 & $\begin{array}{l}\text { IF } P_{\text {GEN }} \text { is } M \text { and } P_{L} \text { is } H \text { and SOC is } L \text {, THEN WP is OFF and BS is } \\
\text { CO }\end{array}$ \\
\hline 13 & $\begin{array}{l}\text { IF } P_{\mathrm{GEN}} \text { is } \mathrm{M} \text { and } \mathrm{P}_{\mathrm{L}} \text { is } \mathrm{L} \text { and } \mathrm{SOC} \text { is } \mathrm{M} \text {, THEN WP is OFF and } \mathrm{BS} \\
\text { is } \mathrm{CD}\end{array}$ \\
\hline 14 & $\begin{array}{l}\text { IF } P_{G E N} \text { is } M \text { and } P_{L} \text { is } M \text { and SOC is } \mathrm{M} \text {, THEN WP is OFF and BS } \\
\text { is } C D\end{array}$ \\
\hline 15 & $\begin{array}{l}\text { IF } P_{G E N} \text { is } \mathrm{M} \text { and } \mathrm{P}_{\mathrm{L}} \text { is } \mathrm{H} \text { and } \mathrm{SOC} \text { is } \mathrm{M} \text {, THEN WP is OFF and } \mathrm{BS} \\
\text { is } \mathrm{CD}\end{array}$ \\
\hline 16 & $\begin{array}{l}\text { IF } P_{\text {GEN }} \text { is } M \text { and } P_{L} \text { is } L \text { and } S O C \text { is } H \text {, THEN WP is OFF and BS is } \\
\text { DO }\end{array}$ \\
\hline 17 & $\begin{array}{l}\text { IF } P_{G E N} \text { is } M \text { and } P_{L} \text { is } M \text { and SOC is } \mathrm{H} \text {, THEN WP is OFF and BS } \\
\text { is DO }\end{array}$ \\
\hline 18 & $\begin{array}{l}\text { IF } P_{\text {GEN }} \text { is } \mathrm{M} \text { and } \mathrm{P}_{\mathrm{L}} \text { is } \mathrm{H} \text { and } \mathrm{SOC} \text { is } \mathrm{H} \text {, THEN } \mathrm{WP} \text { is OFF and } \mathrm{BS} \\
\text { is DO }\end{array}$ \\
\hline 19 & $\begin{array}{l}\text { IF } P_{\text {GEN }} \text { is } \mathrm{H} \text { and } P_{\mathrm{L}} \text { is } \mathrm{L} \text { and } \mathrm{SOC} \text { is } \mathrm{L} \text {, THEN WP is OFF and } \mathrm{BS} \text { is } \\
\mathrm{CO}\end{array}$ \\
\hline 20 & $\begin{array}{l}\text { IF } P_{\text {GEN }} \text { is } \mathrm{H} \text { and } \mathrm{P}_{\mathrm{L}} \text { is M and SOC is } \mathrm{L} \text {, THEN WP is OFF and } \mathrm{BS} \text { is } \\
\mathrm{CO}\end{array}$ \\
\hline 21 & $\begin{array}{l}\text { IF P PEN is } \mathrm{H} \text { and } \mathrm{PL} \text { is } \mathrm{H} \text { and } \mathrm{SOC} \text { is } \mathrm{L} \text {, THEN WP is OFF and BS } \\
\text { is CO }\end{array}$ \\
\hline 22 & $\begin{array}{l}\text { IF } P_{\text {GEN }} \text { is } \mathrm{H} \text { and } \mathrm{P}_{\mathrm{L}} \text { is } \mathrm{L} \text { and } \mathrm{SOC} \text { is } \mathrm{M} \text {, THEN WP is OFF and } \mathrm{BS} \text { is } \\
\mathrm{CD}\end{array}$ \\
\hline 23 & $\begin{array}{l}\text { IF } P_{\text {GEN }} \text { is } \mathrm{H} \text { and } \mathrm{P}_{\mathrm{L}} \text { is } \mathrm{M} \text { and } \mathrm{SOC} \text { is } \mathrm{M} \text {, THEN WP is OFF and } \mathrm{BS} \\
\text { is } \mathrm{CD}\end{array}$ \\
\hline 24 & $\begin{array}{l}\text { IF } P_{\text {GEN }} \text { is } \mathrm{H} \text { and } \mathrm{P}_{\mathrm{L}} \text { is } \mathrm{H} \text { and } \mathrm{SOC} \text { is } \mathrm{M} \text {, THEN WP is OFF and } \mathrm{BS} \\
\text { is CD }\end{array}$ \\
\hline 25 & $\begin{array}{l}\text { IF } P_{\text {GEN }} \text { is } \mathrm{H} \text { and } \mathrm{P}_{\mathrm{L}} \text { is } \mathrm{L} \text { and } \mathrm{SOC} \text { is } \mathrm{H} \text {, THEN WP is } \mathrm{ON} \text { and } \mathrm{BS} \text { is } \\
\text { DO }\end{array}$ \\
\hline 26 & 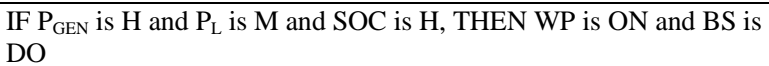 \\
\hline 27 & $\begin{array}{l}\text { IF } P_{\text {GEN }} \text { is } \mathrm{H} \text { and } \mathrm{P}_{\mathrm{L}} \text { is } \mathrm{H} \text { and } \mathrm{SOC} \text { is } \mathrm{H} \text {, THEN WP is } \mathrm{ON} \text { and } \mathrm{BS} \text { is } \\
\text { DO }\end{array}$ \\
\hline
\end{tabular}

Note: $\mathrm{L}$ is low, $\mathrm{M}$ is medium, $\mathrm{H}$ is high, $\mathrm{CO}$ is charge only, $\mathrm{DO}$ is discharge only $\mathrm{CD}$ is charge or discharge, $\mathrm{BS}$ is battery status, and WP is irrigation water pump.

\section{B. Simulink Model of the developed Hybrid System}

Figure 14 shows MATLAB/Simulink model of the hybridization of the two primary sources (solar and micro hydro) and the battery.

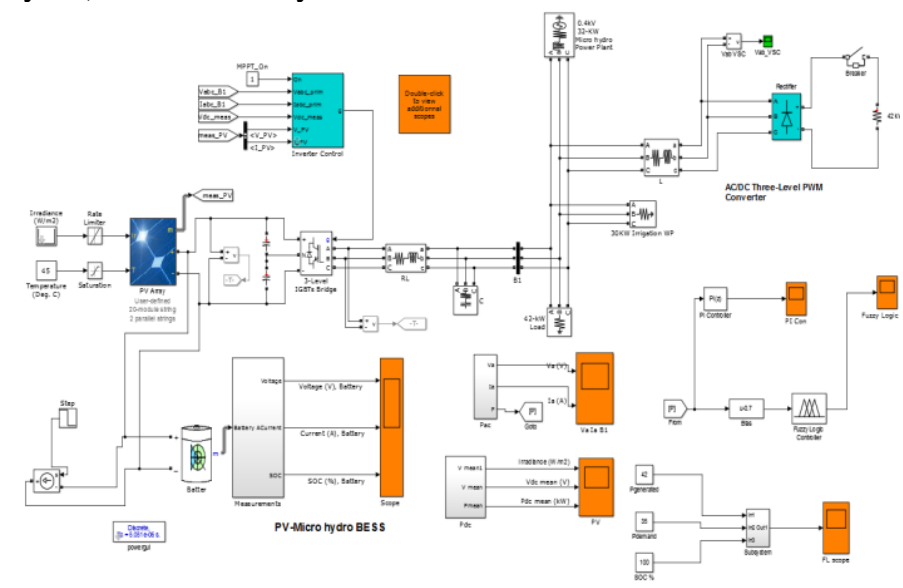

Fig 14: MATLAB/Simulink simulation model of a proposed hybrid PVmicro hydro battery energy storage system

\section{COMPARISON BETWEEN FUZZY LOGIC CONTROLLER AND CONVENTIONAL PI PERFORMANCE}

Rise time is the time required for the response to rise from a specified low value to a specified high value. Fall time is the time taken for the response to decrease (fall) from a specified value to another specified value. Overshoot refers to an output exceeding its final, steady-state value.

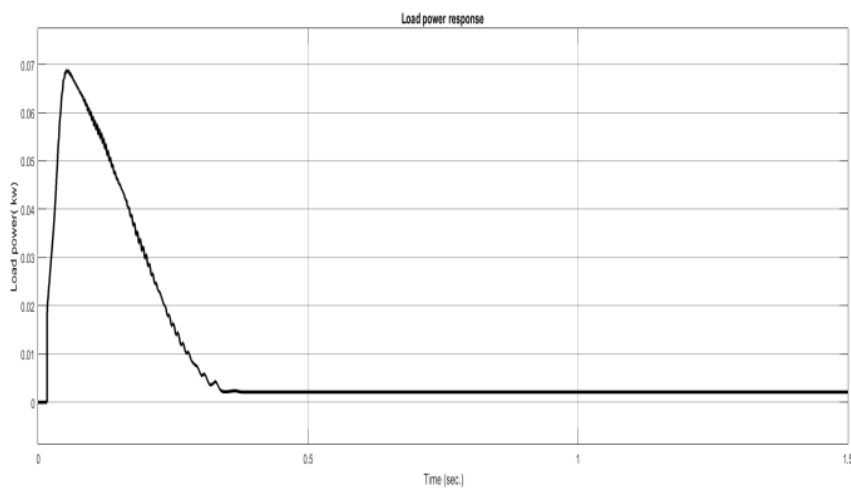

Fig 15: Load power response using conventional PI controller

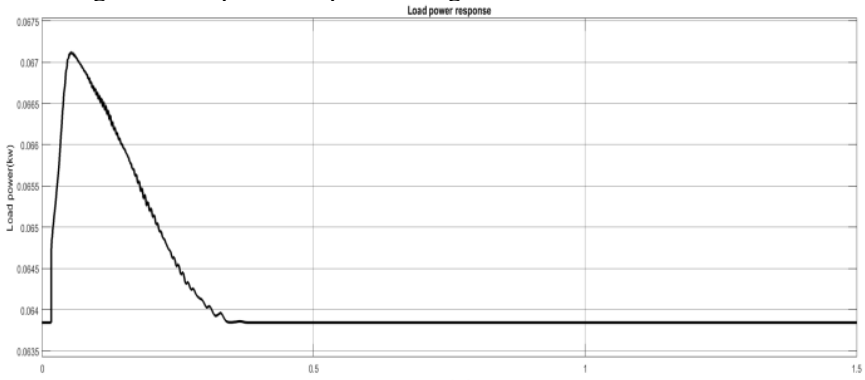

Fig 16: Load power response using fuzzy logic controller

The above figure 15 and figure 16 show the load power response of the PI controller and fuzzy logic controller respectively to be explained in terms of rise time, fall time and overshoot.

Table 6: Load power response comparison using

conventional PI and FLC controllers
\begin{tabular}{|c|l|l|}
\hline Parameters & \multicolumn{1}{|c|}{ PI } & Fuzzy logic \\
\hline Rise time & $26.142 \mathrm{~ms}$ & $26.003 \mathrm{~ms}$ \\
\hline Fall time & $196.22 \mathrm{~ms}$ & $196.034 \mathrm{~ms}$ \\
\hline Overshoot & $0.521 \%$ & $0.505 \%$ \\
& & \\
\hline
\end{tabular}

From Table 6 it is known that the FLC controller has short settling time, low rise time and low overshoot when compared with the conventional PI controller.

\section{CONCLUSION}

The power management among PV array, micro hydro, battery bank, the load, and irrigation water pump was controlled using FLC. Under different scenarios of power generation and power consumption by load the controller performs well and at the same time maintaining the battery SOC within minimum and maximum limits. FLC has three input signals, which are hybrid generated power, demand power and state of charge and two output signals battery controller and irrigation water pump controller. 27 base rules, the COG and Max-Min method are utilized to perform this work.

Through simulation work power management of the developed hybrid PV/micro hydro battery energy storage system by using the FLC is compared to the conventional PI controller. The superior performance is noticeable in terms of rise time, fall time and overshoot. Where, the 
obtained simulation results indicate that the response of the load power in case of using the FLC is better and faster than that obtained in case of using the PI controller.

\section{REFERENCES}

[1] Getnet Zewde Somano, Getachew Shunki, "Design and Modeling of Hybrid Pv-Micro Hydro Power Generation, American Journal of Electrical Power and Energy Systems, 2016

[2] Yohannes Tesfaye, "Hybrid Application of Micro-Hydro Pv/Battery Off- Grid Hybrid Energy System for Ethiopian Rural Area," Master of Science, Addis Ababa University, Aug 2014,

[3] Odax Ugirimbabazi, "Analysis of Power System Options for Rural Electrification in Rwanda", University of Agder, Norway, 25 May 2015

[4] The NASA surface meteorology and solar energy (https://data.nasa.gov/Earth-Science/Surface-Meteorology-andSolar-Energy/wn3p-qsan), Accessed date: 15th July 2018

[5] SNNPRS Regional Mines and Energy Agency, (http://www.snnprswrdb.tripod.com/snnprs), Accessed date: 20th September 2018

[6] GTZ AMES-E, Hawassa, http://www.giz.de/en/profile.html, Accessed date: 20thJuly 2018

[7] Ying Bai and Dali Wang, "Fundamentals of fuzzy logic control fuzzy sets, fuzzy rules and defuzzification", http,//www.springer.com/978-1-84628-468-7,xxv,334 p ,2006

[8] Kim, M., Sohn, Y.-J., Lee, W.-Y., \& Kim, C.-S. "Fuzzy Control Based Engine Sizing Optimization for a Fuel Cell/Battery Hybrid Mini-Bus", Journal of Power Sources, 178, (2), 2008, pp. 706-710

[9] Deeppak K. Bibhuti B. \& A.K. Akella, "Optimization of PV/Wind/Micro Hydro/Diesel Hybrid Power System in HOMER for the Study Area", International Journal on Electrical Engineering and Informatics, Vol.3 No.3, 2011, pp. 307-325

[10] Ahmad B., Amin A. \& Abedalgany A., "Optimal Design of Hybrid Power Generation System to Ensure Reliable Power Supply to Health Center at Umm Jamal, Mafraq, Jordan”, Energy and Environment Research, Vol. 4 No.3, 2014, PP 9-20

[11] Teixera, L.E., Caux J., Beluco A., Bertoldo I., Louzada J.A.S. and Eifler R.C., "Pre-feasibility Study of a Hydro PV Hybrid System Operating at a Dam for Water Supply in Southern Brazil", Journal of Power and Energy Engineering, Vol.3, 2015, PP. 70-83

[12] Dursun, E., \& Kilic, O., "Comparative Evaluation of Different Power Management Strategies of a Standalone PV/Wind/PEMFC Hybrid Power System", Electrical Power and Energy Systems, 34 (1), 2012, pp. 81-89

[13] Wang, C., \& Nehrir, M.H., "Power Management of a Stand-alone Wind/PV/Fuel Cell Energy System. IEEE Trans", Energy Conversion, 23, (3), 2008, pp. 957-967

[14] Tofighi, A., \& Kalantar, M., "Power Management of PV/Battery Hybrid Power Source via Passivity-Based Control, Renewable Energy", 36, (9), 2011, pp. 2440-2450,

[15] Hajizadeh, A., \& Golkar, M.A. "Intelligent Power Management Strategy of Hybrid Distributed Generation System", International Journal of Electrical Power \& Energy Systems, 29, (10), 2007, pp. 783-795,

[16] Li, X., Xu, L., Hua, J., Lin, X., Li, J., \& Ouyang, M., "Power Management Strategy for Vehicular-Applied Hybrid Fuel Cell/Battery Power System", Journal of Power Sources, 191, (2), 2009, pp. 542-549.

[17] St. Clair, David W. Controller Tuning and Control Loop Performance. Straight-Line Control Company Inc. 